\title{
Fractional Current Flow in the Subsurface Using Electrical Resistivity Method: A Laboratory Approach
}

\author{
Podpovršinsko gibanje električnega toka z uporabo \\ električne uporovne metode: laboratorijski pristop
}

\author{
James Adeyemo Adegoke', Gideon Oluyinka Layade ${ }^{2, *}$, Temitayo Kadir ${ }^{1}$ \\ 'Department of Physics, University of Ibadan, Ibadan, Nigeria \\ 2Department of Physics, Federal University of Agriculture, Abeokuta, Nigeria \\ *layadeoluyinka018@gmail.com
}

\begin{abstract}
The authors describe electrical resistivity method using a laboratory experiment, which was conducted in order to calculate the percentage of current that penetrated each layer of soil arranged in a container using Schlumberger array. Four soil samples arranged in three different set-ups were used. The apparent resistivity obtained was interpreted using curve matching techniques and WinResist iteration yielding types A curve, $\mathrm{H}$ curve and A curve, respectively. The interpreted data gave the resistivity of each layer and its thicknesses. The thicknesses obtained from the interpretation were at variance with the actual thicknesses arranged in the container. A multiplier was obtained which serves as a constant in other to obtain the actual thickness. The effective penetration depth of current was determined through the calculated thickness of each layer and the known electrode spacing (AB). The percentage of current that penetrates the layers was found to depend on the electrode spacing as well as the thickness of that layer. Thus, a layer with relatively small thickness has a small percentage of current passing through it compared to a thicker layer.
\end{abstract}

Key words: resistivity, depth, curve, soil, current.

\section{Povzetek}

Raziskava prikazuje električno uporovno metodo z laboratorijskim eksperimentom, ki je bil izveden z namenom izračuna odstotka električnega toka, ki se je gibal preko posamezne plasti zemljine $\mathrm{v}$ posodi, $\mathrm{z}$ uporabo Schlumbergerjeve postavitve elektrod. Uporabljeni so bili štirje različni vzorci zemljine s tremi postavitvami. Pridobljena navidezna upornost je bila interpretirana z uporabo tehnike ujemanja krivulj ter WinResist iteracijskih tipov krivulj A, H in A. Iz interpretacije podatkov so razvidne upornosti posamezne plasti in njena debelina. Pridobljeni rezultati debelin posameznih plasti niso bile skladne z dejanskimi debelinami. Za izračun dejanske debeline je bil zato pridobljen in uporabljen korekcijski faktor, ki služi kot konstanta. Efektivna globina prodiranja električnega toka je bila določena preko izračunane debeline posamezne plasti in znane razdalje med elektrodama $(\mathrm{AB})$. Odstotek električnega toka, ki prodira preko plasti, je bil odvisen od razmika med elektrodama ter debelino plasti. Tako ima plast zemljine $\mathrm{z}$ razmeroma majhno debelino v primerjavi $\mathrm{z}$ večjo debelino majhen odstotek toka, ki prehaja skoznjo.

Ključne besede: upornost, globina, krivulja, zemljina, električni tok. 


\section{Introduction}

The electrical resistivity method is a geophysical prospecting method in which electrical current is transmitted through copper electrodes to the ground for the determination of the electrical properties of subsurface [1-3]. Two types of electrodes are involved in the resistivity surveying method and they are current and potential electrodes. A pair of current electrode is used to transfer current into the ground, while the same pair of potential electrode is employed to measure the potential drop [4]. In other words, the resistivity meter calculates the current flow resistance. The distribution of resistivity of the volume of sounding soil is determined by the electrical resistivity surveys. The possible patterns of differences in result provide information on the form of heterogeneities in the subsurface and their corresponding electrical properties [5, 6].

Resistivity measurements are also based on rock composition, interstitial fluids, temperature and pore geometry. Such parameters influence the electrical resistivity of the soil, but in various ways and in varying degrees [7-9]. Electrical geophysical methods allow soil electrical properties to be measured non-destructively, cost-effectively and quickly $[10,11]$. Over the years, engineering studies and groundwater exploration are on the increase as a result of geophysical survey. This is made possible due to the swift advances in software development and associated numerical modelling solutions which have shown the way to the development of the present day technology [12-14].

Studies have shown that vertical electrical sounding (VES) and electrical profiling are the two ways by which electrical resistivity survey can be conducted $[6,15,16]$. VES is applicable for the study of horizontal and near-horizontal interfaces. The procedures involve positioning of both the current and potential electrodes at the same relative spacing. The range is gradually expanded around a fixed central point while electrical profiling is used to assess lateral resistivity variations. The current and potential electrodes are retained and gradually moved along a profile at a fixed distance [6, $17,18]$. This research is aimed at determining the relationship that exists between electrode separation and the percentage of current passing at a particular depth based on the arrangement of layers.

\section{Theoretical background}

Resistivity varies with conductivity inversely. A high-conductivity surface therefore has low resistivity and vice versa. The relationship between resistivity $(\rho)$ and conductivity $(\sigma)$ is presented as Equation (1);

$\rho=1 / \sigma$

The principle of electrical resistivity is based on Ohms' law which state that "the current flowing through a metallic conductor is proportional to the potential difference across its end provided other conditions are kept constant".

Mathematically, it is defined as V = IR

Where $\mathrm{V}$ is the Voltage in volts, I is the current in Amps and R is the resistance in Ohms.

The current density (J) and the Electric filed (E) are related through Ohms' law by Equation

(2) where E is in volts per meter and $\sigma$ is the conductivity of the medium in Siemens per meter $(\mathrm{S} / \mathrm{m})$

$\mathrm{J}=\sigma \mathrm{E}$

The Electric field is the gradient of the scalar potential

$\mathrm{E}=-\nabla \mathrm{V}$

Thus we have

$\mathrm{J}=-\sigma \nabla \mathrm{V}$

Taking the gradient of both side

$\nabla . \mathrm{J}=-\nabla \cdot(\sigma \nabla \mathrm{V})$

But $\Delta . \mathrm{J}=0$

$\nabla \cdot(\sigma \nabla \mathrm{V})=0$

$\nabla \sigma . \nabla \mathrm{V}+\sigma \nabla^{2} \mathrm{~V}=0$

The Equation (6) becomes Laplace if $\sigma$ in the first term is constant and disappear, that is, the potential is harmonic which is stated as follows: 

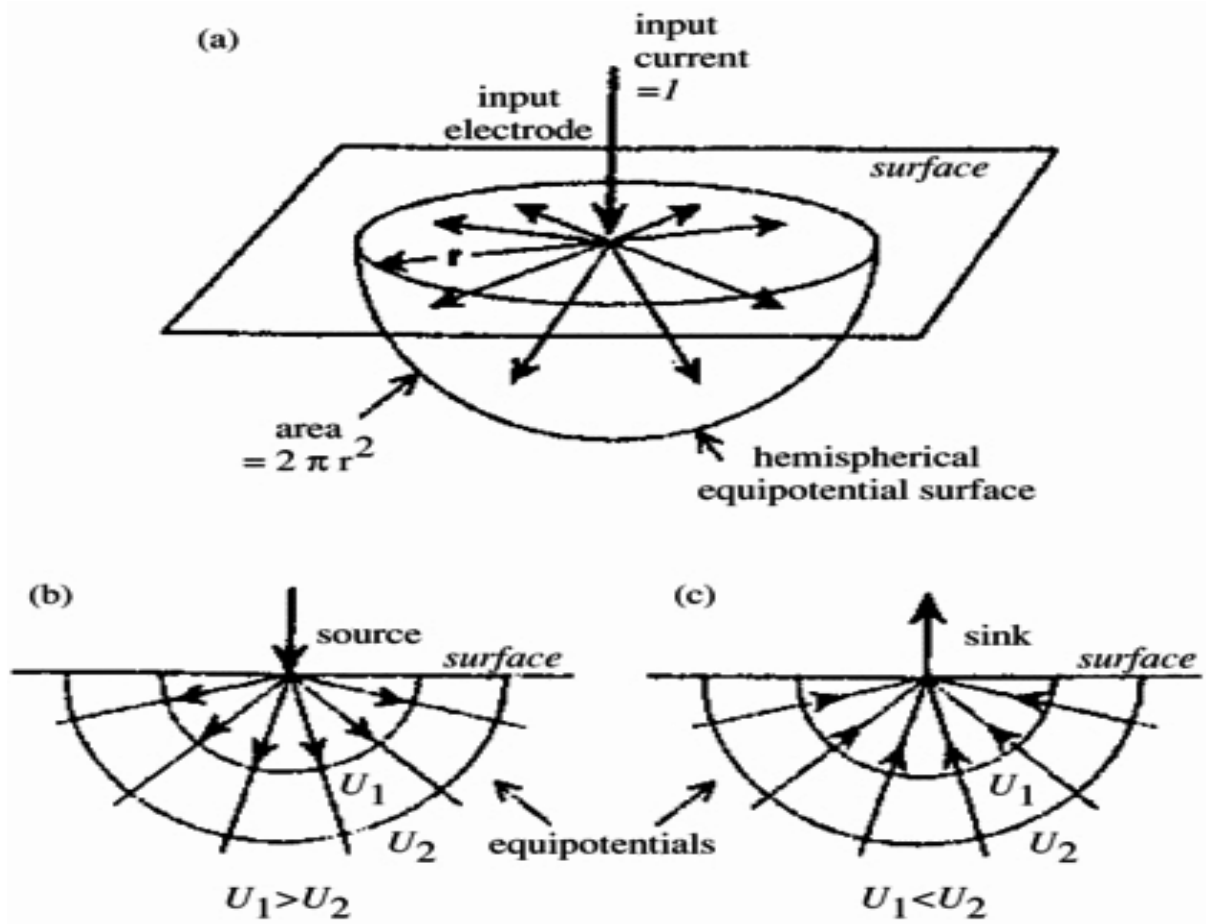

Figure 1: Electric field lines and equipotential surfaces on the surface of a uniform half-space around a single electrode: (A) hemispheric equipotential surfaces, (B) radially outward field lines around a source, and (C) radially inward field lines around a sink [19].

$$
\nabla^{2} \mathrm{~V}=0
$$

\section{The potential of a single electrode}

The current (I) is injected into a homogeneous half-space, with a specific electrical conductivity $(\sigma)$ and resistivity $(\rho)$. The current passes under the surface in all directions, but does not flow through the surface. The electric field lines are parallel to the current flow and normal to the hemisphere-shaped equipotential surfaces. Hence, the current density J as a function of radius $r$ is written as

$\mathrm{J}=\frac{\mathrm{I}}{2 \pi \mathrm{r}^{2}}$

But $\mathrm{E}=\rho \mathbf{J}$

Therefore, $E=\frac{\rho J}{2 \pi r^{2}}$

Now, $\mathrm{E}=-\nabla \mathrm{V}=-\frac{\partial \mathrm{V}}{\partial \mathrm{r}}=-\frac{\rho \mathrm{J}}{2 \pi \mathrm{r}^{2}}$
Integrating Equation (10), the equation for the potential can be stated as follows

$\mathrm{V}=\frac{\rho \mathrm{J}}{2 \pi \mathrm{r}}$

for a point source at the surface of the halfspace.

\section{The four-electrode method}

Among the existing geophysical techniques, the resistivity method is generally and mostly used for shallow subsurface studies and groundwater exploration [20]. Four electrodes are used in this method to measure resistivity [21]. One pair of electrodes is used to penetrate the current into the ground and another pair is used to measure the potential difference of hemispheric equipotential surfaces where the ground surface is intersecting them [22]. This is the conventional way in which resistivity is measured in uniform half space [23]. Figure 2 


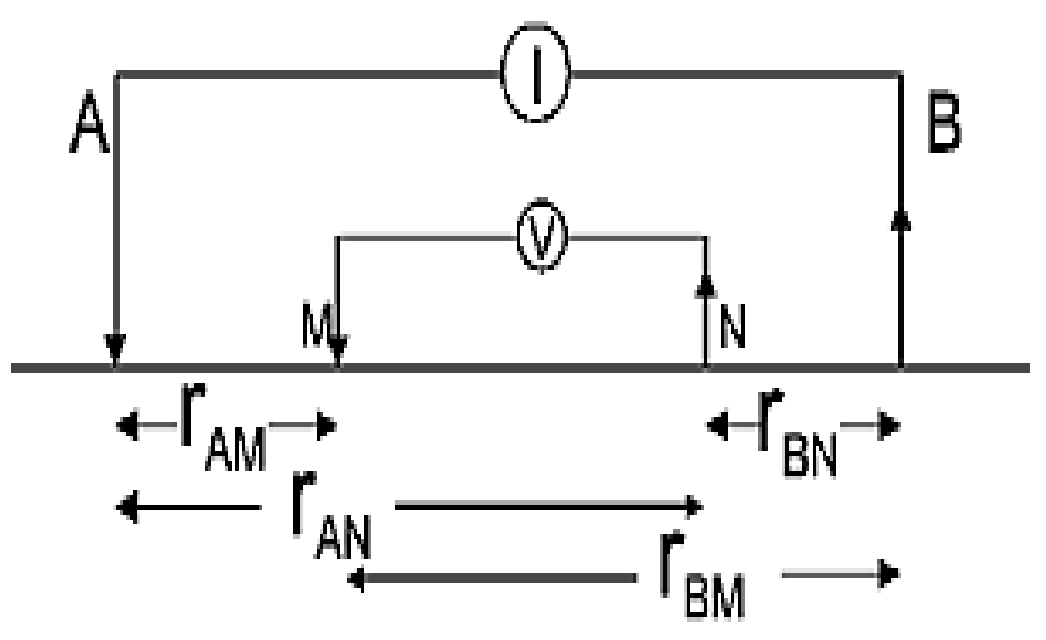

Figure 2: General resistivity measurement method of four electrodes.

shows the basic configuration of four electrodes for measuring resistivity.

The current electrodes, A and B act as source and sink, respectively. The potential at the electrode $M$ due to the source $A$ is $+\frac{\mathrm{pl} /}{2 \pi \pi_{A M}}$ while $\operatorname{sink} B$ is $-\mathrm{\rho l}^{\mathrm{P}} / 2 \pi_{\mathrm{BM}}$. The combined potential (V) at $\mathrm{M}$ is $\left(V_{M}\right)$ which relates the resistivity $(\rho)$, current (I) and distance ( $r$ ) between the source and sink is presented in Equation (11) as;

$\mathrm{V}_{\mathrm{M}}=\frac{\rho \mathrm{I}}{2 \pi}\left(\frac{1}{\mathrm{r}_{\mathrm{AM}}}-\frac{1}{\mathrm{r}_{\mathrm{BM}}}\right)$

Similarly, at N, the combined potential is

$\mathrm{V}_{\mathrm{N}}=-\frac{\rho \mathrm{I}}{2 \pi}\left(\frac{1}{\mathrm{r}_{\mathrm{AN}}}-\frac{1}{\mathrm{r}_{\mathrm{BN}}}\right)$

The potential difference measured between $\mathrm{M}$ and $\mathrm{N}$,

$$
\begin{aligned}
& \mathrm{V}=\mathrm{V}_{\mathrm{M}}+\mathrm{V}_{\mathrm{N}} \\
& \mathrm{V}=\frac{\rho \mathrm{I}}{2 \pi}\left\{\left(\frac{1}{\mathrm{r}_{\mathrm{AM}}}-\frac{1}{\mathrm{r}_{\mathrm{MB}}}\right)-\left(\frac{1}{\mathrm{r}_{\mathrm{AN}}}-\frac{1}{\mathrm{r}_{\mathrm{BN}}}\right)\right\}
\end{aligned}
$$

Then the resistivity ( $\rho$ ) can be determined using the following formula stated here: $\rho_{\mathrm{a}}=\frac{2 \mathrm{~V} \pi}{\mathrm{I}}\left\{\left(\frac{1}{\mathrm{r}_{\mathrm{AM}}}-\frac{1}{\mathrm{r}_{\mathrm{MB}}}\right)-\left(\frac{1}{\mathrm{r}_{\mathrm{AN}}}-\frac{1}{\mathrm{r}_{\mathrm{BN}}}\right)\right\}^{-1}$

So, from the above equation we derive

$\rho_{\mathrm{a}}=\frac{2 \mathrm{~V} \pi}{\mathrm{I}} \mathrm{k}$

where $\mathrm{k}$ is the geometric factor.

\section{Apparent resistivity}

Apparent resistivity is the volumetric average of a heterogeneous half-space, through a complex weighing function depending on the configurations of the electrode [24, 25]. On the other hand, true resistivity is the measured relationship between the current applied and the potential difference of an electrically homogeneous and isotropic half-space for a particular electrode arrangement and spacing [3]. This in situ resistivity is supposed to be homogeneous but not in a real situation, it gives the apparent resistivity of an equivalent uniform half-space and does not represent the ground's true resistivity [19]. The resistivity of the underlined layers is obtained from the measurement taken using a resistivity meter. Thus, apparent resistivity $\left(\rho_{a}\right)$ is obtained by multiplying measured value by the geometric factors [26] under the assumption that the 


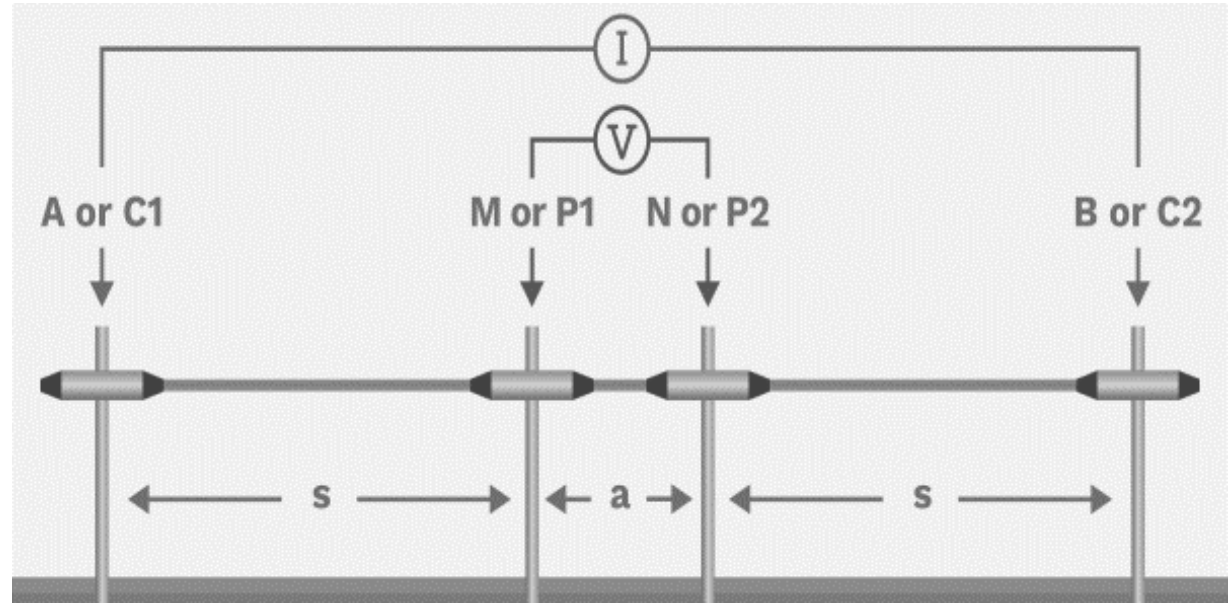

Figure 3: Schlumberger array for resistivity measurement, consisting of a pair of current electrodes $(A, B)$ and a pair of potential electrodes $(M, N)$.

ground is uniform; therefore, the measured resistivity is only the apparent resistivity and not the ground's true resistivity. Depending on the resistivity value of the layers underlined, the apparent resistivity increases or decreases with electrode spacing.

\section{Schlumberger configurations}

Schlumberger array used for VES investigation $[11,21]$, is a type of direct current resistivity survey described by its configuration. It makes use of four collinear electrodes, a pair of current electrodes as source and another pair of potential electrodes as the receivers. The potential electrodes are arranged in between the current electrodes; the central point is kept constant while the distance between the current electrodes is increased so that current can penetrate far down into the ground while the potential electrode is moved only when the voltage becomes too small to measure [27]. This arrangement enhances the capacity of the current to penetrate into greater depths, as the conductivity is distributed vertically [19]. The Figure 3 shows the Schlumberger configuration for resistivity measurement;

Let the separations between current and potential electrode be $(2 s+a)$ and $a$. This transforms Equation (14) as follows:

$$
\mathrm{r}_{\mathrm{AM}}=\mathrm{s} ; \mathrm{r}_{\mathrm{MB}}=\mathrm{s}+\mathrm{a} ; \mathrm{r}_{\mathrm{AN}}=\mathrm{s}+\mathrm{a} ; \mathrm{r}_{\mathrm{BN}}=\mathrm{s}
$$

$\rho_{\mathrm{a}}=\frac{2 \mathrm{~V} \pi}{\mathrm{I}}\left\{\left(\frac{1}{\mathrm{r}_{\mathrm{AM}}}-\frac{1}{\mathrm{r}_{\mathrm{MB}}}\right)-\left(\frac{1}{\mathrm{r}_{\mathrm{AN}}}-\frac{1}{\mathrm{r}_{\mathrm{BN}}}\right)\right\}^{-1}$

$\rho_{\mathrm{a}}=\frac{2 \mathrm{~V} \pi}{\mathrm{I}}\left\{\left(\frac{1}{\mathrm{~s}}-\frac{1}{\mathrm{~s}+\mathrm{a}}\right)-\left(\frac{1}{\mathrm{~s}+\mathrm{a}}-\frac{1}{\mathrm{~s}}\right)\right\}^{-1}$

$\rho_{\mathrm{a}}=\frac{2 \mathrm{~V} \pi}{\mathrm{I}}\left\{\frac{\mathrm{s}+\mathrm{a}-\mathrm{s}-\mathrm{s}+\mathrm{s}+\mathrm{a}}{\mathrm{s}(\mathrm{s}+\mathrm{a})}\right\}^{-1}$

$\rho_{\mathrm{a}}=\frac{2 \mathrm{~V} \pi}{\mathrm{I}}\left\{\frac{2 \mathrm{a}}{\mathrm{s}(\mathrm{s}+\mathrm{a})}\right\}^{-1}$

$\rho_{\mathrm{a}}=\frac{2 \mathrm{~V} \pi}{\mathrm{I}}\left\{\frac{\mathrm{s}(\mathrm{s}+\mathrm{a})}{2 \mathrm{a}}\right\}$

$\rho_{\mathrm{a}}=\frac{\mathrm{V} \pi}{\mathrm{I}}\left\{\frac{\mathrm{s}(\mathrm{s}+\mathrm{a})}{\mathrm{a}}\right\}$

\section{Materials and method}

\section{Data acquisition}

The research procedure was carried out at the geophysics research laboratory located at the Department of Physics, University of Ibadan. It was done using a tabletop model system made 
of a perspex container with a total depth of $29 \mathrm{~cm}$ and a length of $120 \mathrm{~cm}$. Four samples of soil were used which were arranged in the transparent perspex container at different proportions. The experiment was done three times with three different arrangements. The arrangement from top to bottom is as follows;

- A three-layer soil containing humus $(7 \mathrm{~cm})$, sandy clay $(10 \mathrm{~cm})$ and sand $(12 \mathrm{~cm})$ which all together make a depth of $29 \mathrm{~cm}$.

- A three-layer soil consisting of clay $(4 \mathrm{~cm})$, sandy clay $(10 \mathrm{~cm})$ and sand $(15 \mathrm{~cm})$ which all together make a depth of $29 \mathrm{~cm}$.

- A two-layer soil consisting of clay $(7 \mathrm{~cm})$ and sand $(11 \mathrm{~cm})$ which make a depth of $18 \mathrm{~cm}$.

In each of the arrangements, the soil samples were compacted one after the other to reduce the pore space in-between the soil particles and the moisture content was regulated. Electrical resistivity survey using Schlumberger array was carried out on each of the arrangements using Geopulse Tigre resistivity meter, first on three-layer arrangements which are humus, sandy-clay, and sand; then, clay, sandy-clay and sand; and lastly, a two-layer arrangement of clay and sand. The current electrode spacing starting from $1.0 \mathrm{~cm}$ to $55.0 \mathrm{~cm}$ and potential electrode spacing starting from $0.25 \mathrm{~cm}$ to $5.0 \mathrm{~cm}$ were used for measurement. Copper wire was used as probes in place of the copper electrode. A current of $0.5 \mathrm{~mA}$ was sent into the soil through the electrodes placed at two points with equal distance apart from the central point. The potential difference between the two points was measured using the resistivity meter in W-cm. Six measurements were taken in all, two for each arrangement for certainty purpose.

\section{Results and discussion}

Data acquired in centimetres were converted to meters and multiplied with the geometric factor $(\mathrm{K})$ to obtain the apparent resistivity. The $\mathrm{AB} / 2$ was plotted against apparent resistivity and interpreted using a 2 layer master curve and WinResist. The mean of the thicknesses of each arrangement was mathematically simulated to

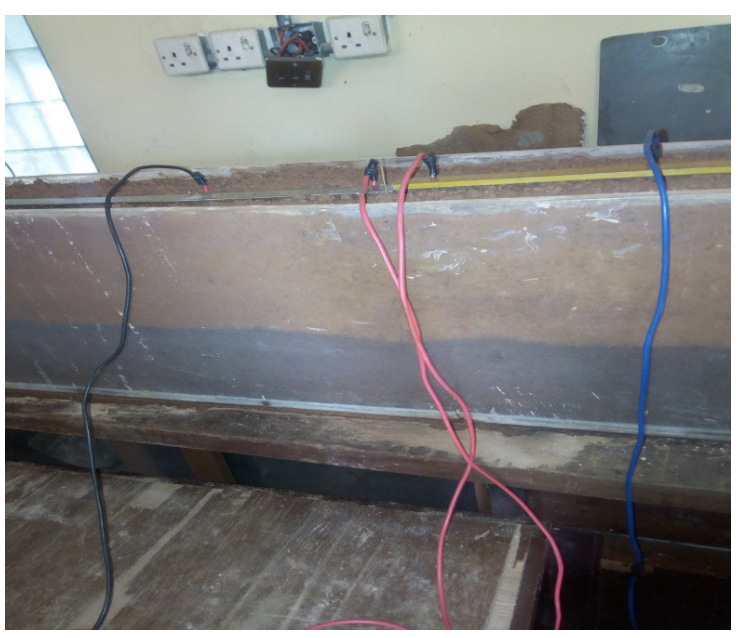

Figure 4: The laboratory setup of three soil layers in a container.

obtain a constant value of 6.03 which serves as a multiplier to obtaining a value close to the real value. The thicknesses obtained were used to calculate the fraction of current that penetrated each layer using the equation for current (I) distribution in a uniform half space as stated in Equation (22); where I $x$ depends upon the current electrode spacing $L$ :

$\frac{I_{X}}{I}=\left\{\frac{2}{\pi} \tan ^{-1} \frac{2 z_{1}}{L}\right\}$

The fraction of current between any two depths is obtained from the difference in the fractions above each depth, calculated with Equation (22).

\section{First arrangement}

The first arrangement contains humus, sandyclay, and sand. The curve is a type-A curve that showed an increase in the resistivity value with depth in Figures 5 and 6, respectively. This indicates that the resistivity of humus is lower than that of sandy clay and the sandyclay is lower than that of sand. This result is due to the degree of water saturation in the soil type. This factor depends on the porosity, permeability and the interconnectivity of pore spaces in the rock type. Humus and sandy clay have lower resistivity of $23.15 \mathrm{~W}$-m and 

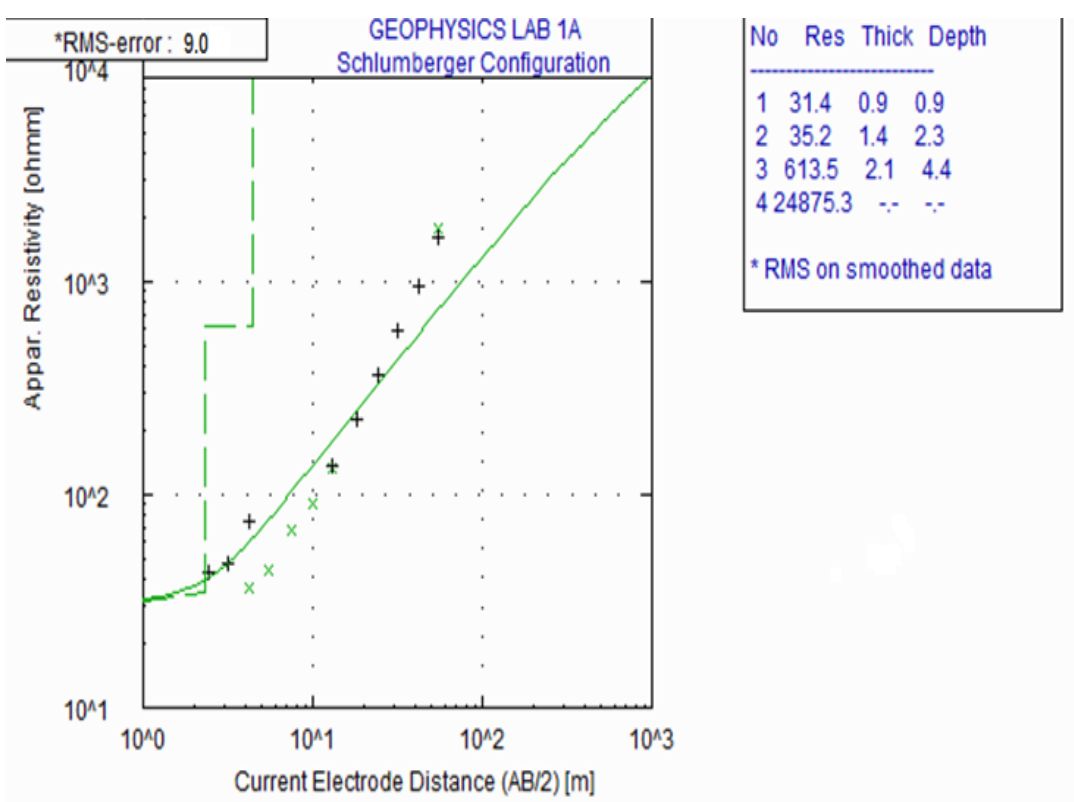

Figure 5: Resistivity measurement of soil layers against electrode spacing $(A B / 2)$ for the first arrangement.

43.8 $\mathrm{W}$-m, respectively, while sand has a higher resistivity of $757.95 \mathrm{~W}$-m. Humus and sandyclay have more porosity than sand because porosity decreases with grain size but they are less permeable, that is, they allow less water to flow. Sand in its case is less porous than humus and sandy-clay but its permeability is higher, so more water flows through it. It cannot hold water like the two types of rocks discussed earlier. This accounts for its high resistivity. The fourth layer is assumed as the plastic container whose resistivity value is very high and can be taken to be infinity. The thicknesses obtained are 5.0, 7.0 and 12.0 for the first layer, second layer and third layer, respectively, against the real values of 7.0, 10.0 and 12.0. The fraction of current passing through each layer is calculated using Equation (16) and it is 6\% for first layer, $8 \%$ for second layer and $14 \%$ for the third layer.

\section{Second arrangement}

The second arrangement contains clay, sandyclay and sand. The sand was made to serve as an aquifer as the base of the container was sealed and the flow of water out of it was restricted. In Figures 7 and 8, the curve is a type- $\mathrm{H}$ curve which demarcates the resistivity of each layer. Clay and sandy-clay have higher resistivity of
$122 \mathrm{~W}$-m and $161.7 \mathrm{~W}$-m, respectively, while the resistivity of sand is $27 \mathrm{~W}-\mathrm{m}$. These values clearly show that in this particular experiment, the clay and the sandy-clay were less saturated compared to the sand. Sand is a good aquifer because of its high permeability property; therefore, it allows the flow of water. The fourth layer is assumed as the plastic container whose resistivity value is very high and can be taken to be infinity. The thicknesses obtained are 5.0, 11.0 and 34.0 for the first layer, second layer and third layer, respectively, against the real values of 4.0, 10.0 and 15.0. The fraction of current through each layer is calculated using Equation (16) and the values obtained are 6\% for first layer, 13\% for second layer and 35\% for the third layer.

\section{Third arrangement}

The third arrangement contains clay and sand. The curve obtained in Figures 9 and 10 is a type-A curve which shows that there is a direct relationship between the increases of resistivity and depth. The resistivity of clay is $67 \mathrm{~W}$-m while that of sand is $301.15 \mathrm{~W}$-m. The value of resistivity obtained for each layer of rock shows the degree of saturation of each layer, and which indicates that the clay held 


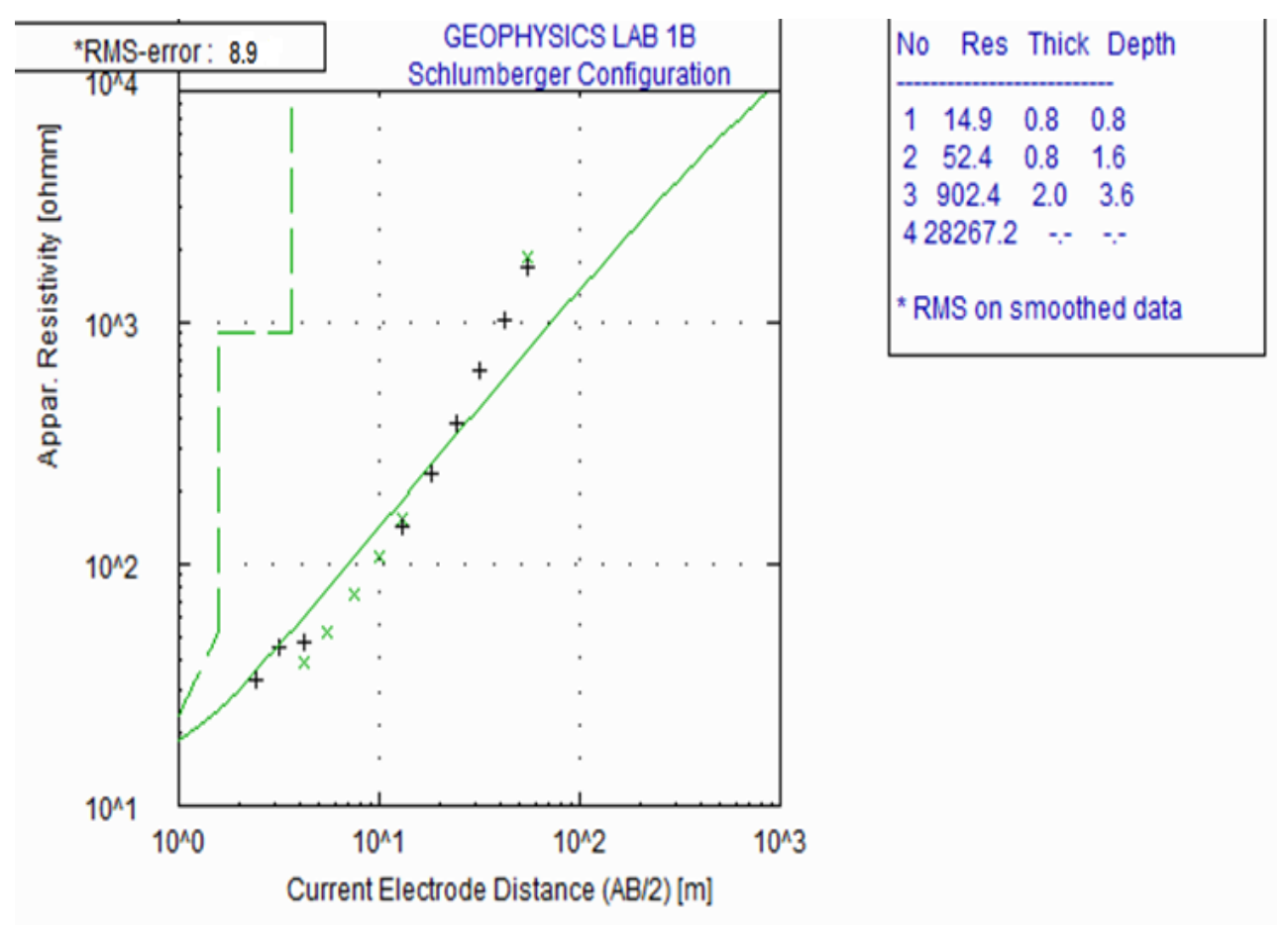

Figure 6: Resistivity measurement (repeated) of soil layers against electrode spacing $(A B / 2)$ for the first arrangement.

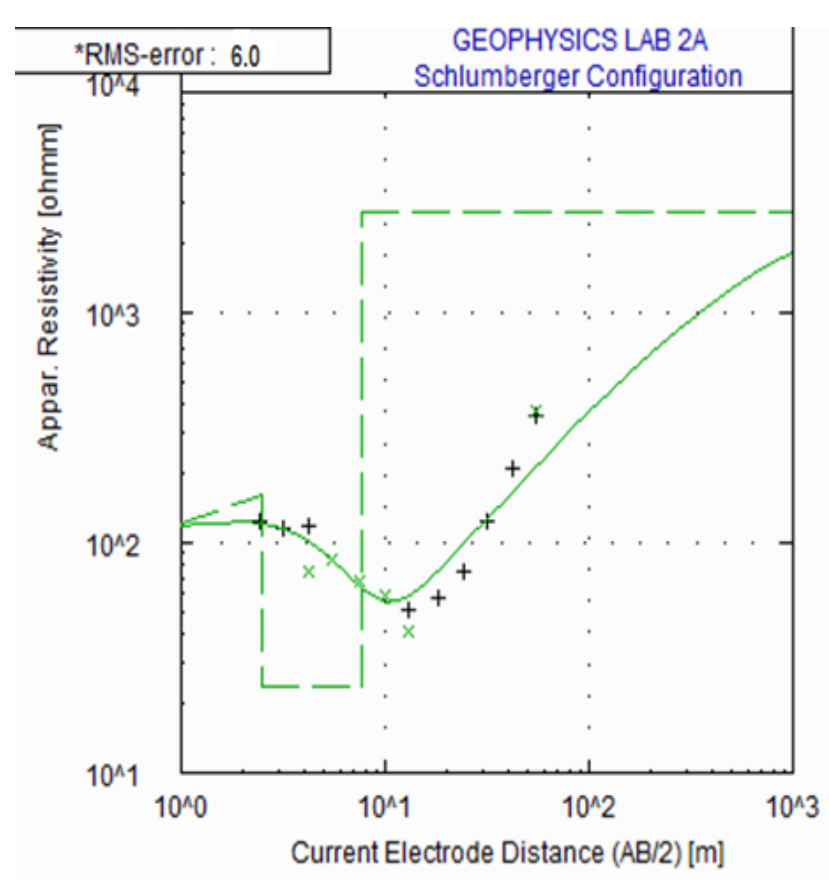

\begin{tabular}{|lccc|} 
No & Res & Thick & Depth \\
\hline 1 & 114.5 & 0.9 & 0.9 \\
2 & 161.9 & 1.6 & 2.5 \\
3 & 23.8 & 5.2 & 7.7 \\
4 & 2763.8 & - & - \\
* & \\
\end{tabular}

Figure 7: Resistivity measurement of soil layers against electrode spacing $(A B / 2)$ for the second arrangement. 


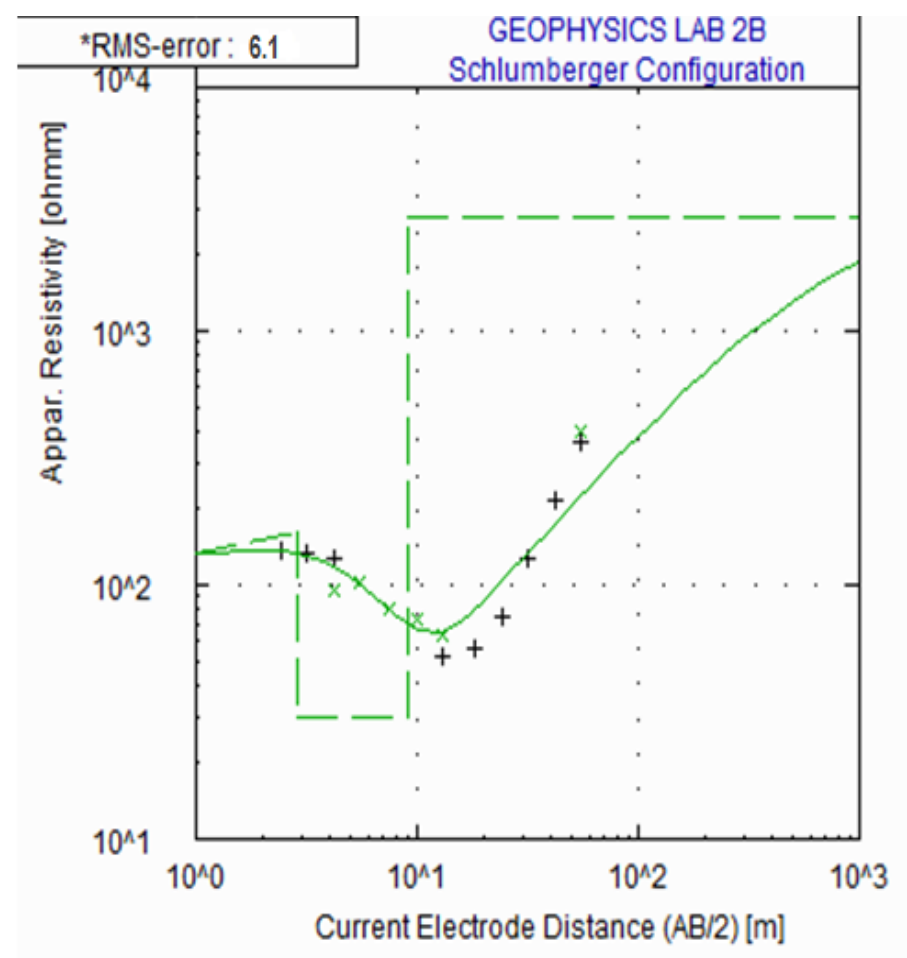

No Res Thick Depth

$\begin{array}{llll}1 & 131.3 & 0.9 & 0.9\end{array}$

$\begin{array}{llll}2 & 161.4 & 2.0 & 2.9\end{array}$

$\begin{array}{llll}3 & 30.2 & 6.3 & 9.2\end{array}$

$42810.6 \quad \because-\cdots$

${ }^{*}$ RMS on smoothed data

Figure 8: Resistivity measurement (repeated) of soil layers against electrode spacing (AB/2) for the second arrangement.

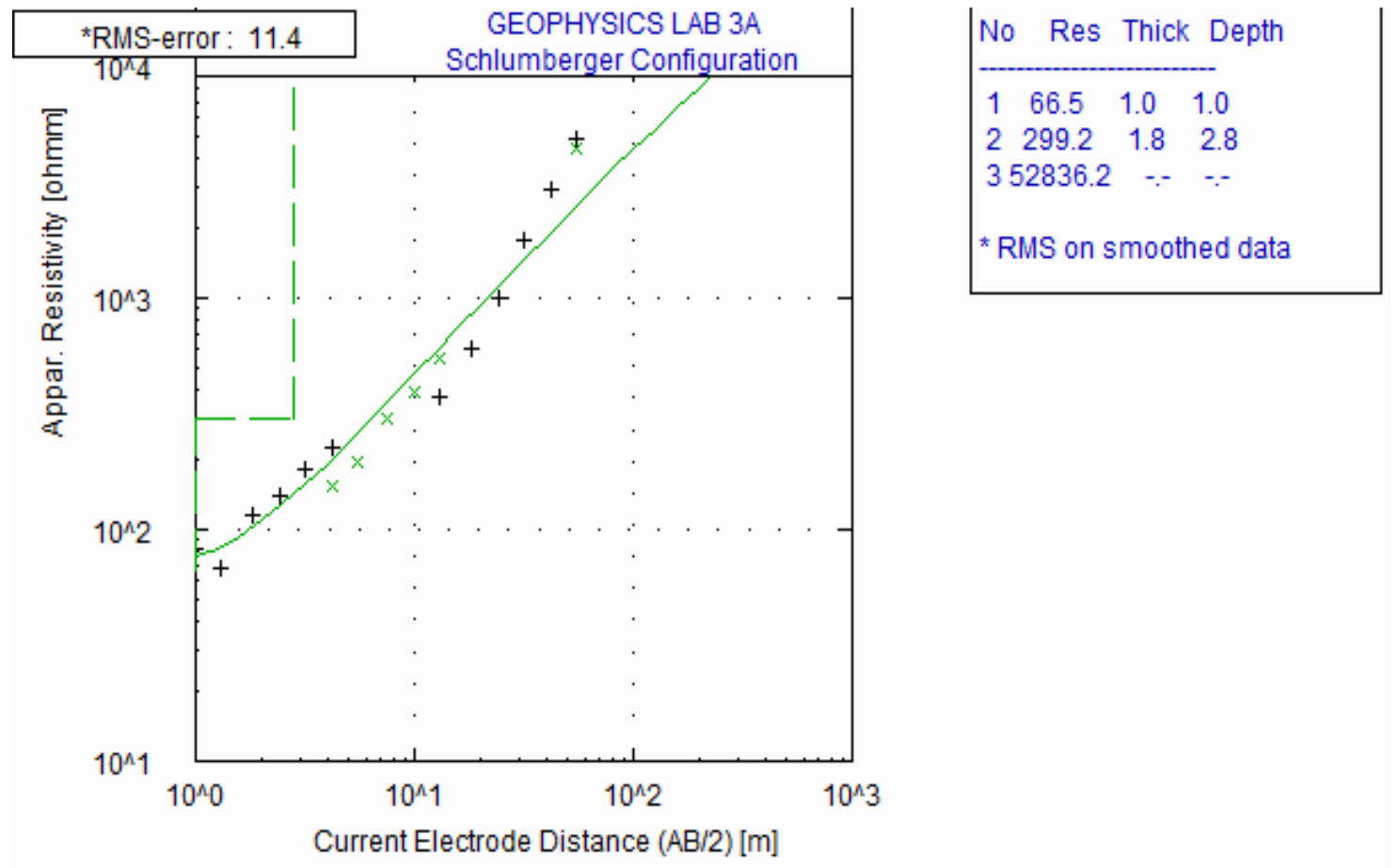

Figure 9: Resistivity measurement of soil layers in a container against electrode spacing (AB/2) for the third arrangement. 

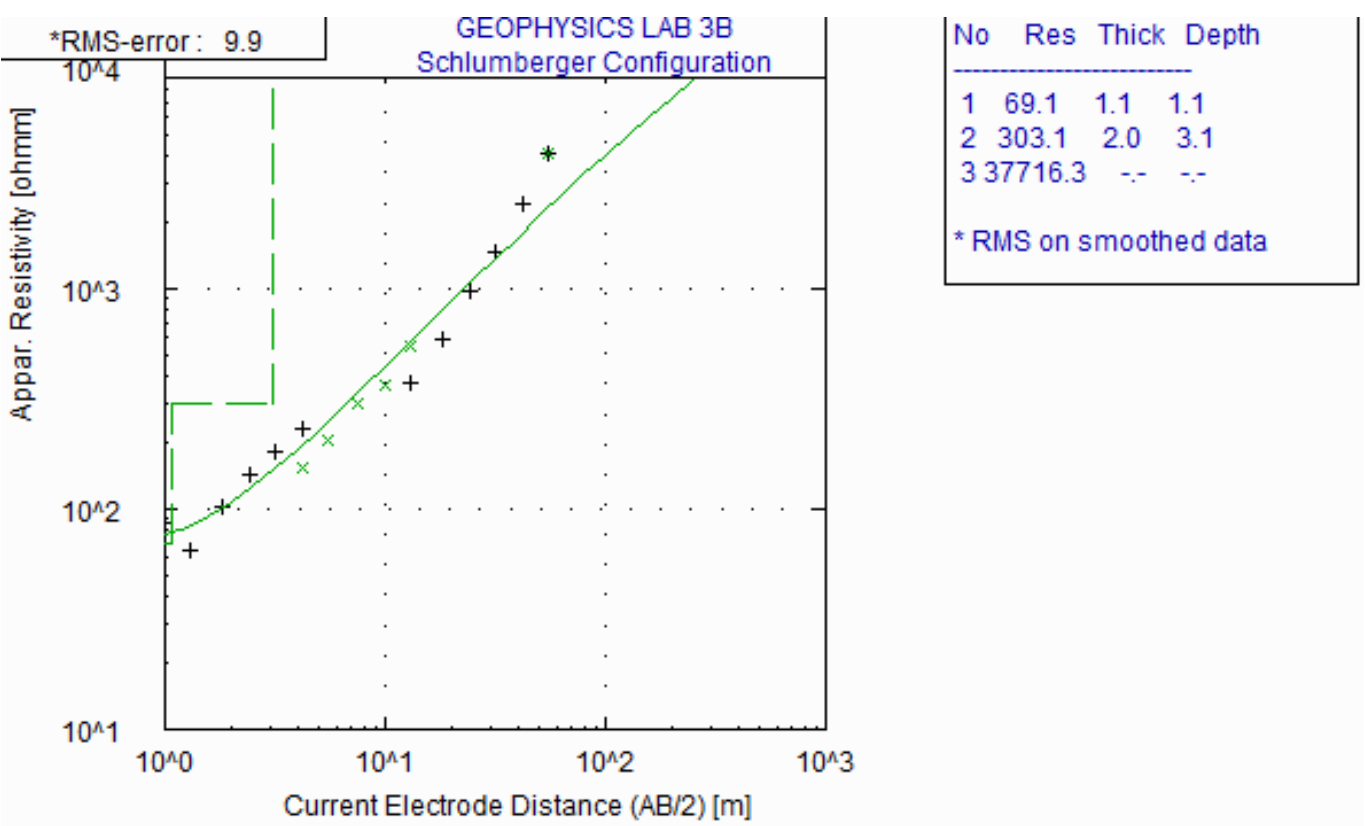

Figure 10: Resistivity measurement (repeated) of soil layers in a container against electrode spacing (AB/2) for the third arrangement.

more moisture content and therefore is more conductive than the sand. The third layer is assumed to be the plastic container whose resistivity value is very high and can be taken to be infinity. The thicknesses obtained are 6.0 and 11.0 for the first layer and second layer, respectively, against the real values of 7.0 and 12.0. The fraction of current passing through each layer is calculated using Equation (16) and the values are $7 \%$ for first layer and $14 \%$ for second layer.

\section{Conclusion}

The percentage of current penetrating each layer shows that the effective current penetration depth depends on the spacing of electrodes. When the electrode spacing is increased, the effective current penetration depth is also increased. This is true when compared to Lowrie, 2007 who stated when $\mathrm{Z}=\mathrm{L} / 2,50 \%$ of the current penetrates while about $90 \%$ of the current flows in the same layer when $\mathrm{Z}=3 \mathrm{~L}$. This implies that the percentage of current passing through a layer of shallow thickness is lower than that of passing through a deeper layer. Therefore, in electrical resistivity survey method, the subsurface depth being investigated should be considered for current needed.

\section{References}

[1] Archie, G.E. (1942): The electrical resistivity log as an aid in determining some reservoir characteristics. Society of Petroleum Engineers, 146(1), pp. 54-61, DOI: 10.2118/942054-G.

[2] Fukue, M., Minato, T., Horibe, H., Taya, N. (1999): The microstructures of clay given by resistivity measurements. Engineering Geology, 54(1-2), pp. 43-53, DOI: 10.1016/S0013-7952(99)00060-5.

[3] Meindinyo, R.O.K., Utuedeye, O, Adedokun, I.O. (2017): Vertical electrical sounding (Ves) for the determination of under ground resistivity in part of Nigeria Wilberforce Island, Amassoma, Bayelsa State. IOSR Journal of Research \& Method in Education, 7(2), pp. 53-61, DOI: 10.9790/7388-0702035361.

[4] Coker, J. O. (2012): Vertical electrical sounding (VES) methods to delineate potential groundwater aquifers in Akobo area, Ibadan, South-western, Nigeria. 
Journal of Geology and Mining Research, 4(2), pp. 35-42, DOI: 10.5897/JGMR11.014.

[5] Ghosh, D.P. (1971): The application of linear filter theory to the direct interpretation of geo-electrical resistivity sound measurement. Geophysical Prospecting, 11(4), pp. 471-508, DOI: 10.1111/ j.1365-2478.1971.tb00593.x.

[6] Kearey, P., Brooks, M., Hill, I. (2002): An introduction to geophysical exploration. Blackwell Science.

[7] Gupta, S.C., Hanks, R.J. (1972): Influence of water content on electrical conductivity of the soil. Proceedings of Soil Science Society of America, 36(6), pp. 855-857, DOI: 10.2136/ sssaj1972.03615995003600060011x.

[8] Herman, R. (2001): An introduction to electrical resistivity in geophysics. American Journal of Physics, 69(9), pp. 943-952, DOI: 10.1119/1.1378013.

[9] Hossain, Z., Cohen, A.J. (2012): Relationship among porosity, permeability, electrical and elastic properties. SEG Technical Program Expanded Abstracts, pp. 1-5, DOI: 10.1190/segam2012-1496.1.

[10] Giao, P.H., Chung, S.G., Kim, D.Y., Tanaka, H. (2003): Electric imaging and laboratory resistivity testing for geotechnical investigation of Pusan clay deposits. Journal of Applied Geophysics, 52(4), pp. 157-175, DOI: 10.1016/S0926-9851(03)00002-8.

[11] Syed, B.A., Siddiqui, F.I. (2012): Use of vertical electrical sounding (VES) method as an alternative to standard penetration test (SPT). Proceedings of the Twenty-second International Offshore and Polar Engineering Conference Rhodes, Greece, June 17-22.

[12] Kalinski, R.J., Kelly, W.E. (1993): Estimating water content of soils from electrical resistivity. Geotechnical Testing Journal, 16(3), pp. 323-329, DOI: 10.1520/GTJ10053J.

[13] Jatau, B.S., Patrick, N.O., Baba, A., Fadele, S.I. (2013): The use of vertical electrical sounding (VES) for subsurface geophysical investigation around Bomo area, Kaduna state, Nigeria. IOSR Journal of Engineering (IOSRJEN), 3(1), pp. 10-15, DOI: 10.9790/3021-03141015.

[14] Layade, G.O., Adegoke, J.A., Oladewa, F.C. (2017): Hydro geophysical Investigation for groundwater development at Gbongudu Area, Akobo Ojurin, Ibadan, Southwestern Nigeria. Journal of Applied Sciences and Environmental Management, 21(3), pp. 527-535, DOI: 10.4314/jasem.v21i3.14.

[15] McCarter, W.J., Desmazes, P. (1997): Soil characterization using electrical measurements. Géotechnique, 47(1), pp. 179-183, DOI: 10.1680/ geot.1997.47.1.179.
[16] McCarter, W.J. (1984): The electrical resistivity characteristics of compacted clays. Géotechnique, 34(2), pp. 263-267, DOI: 10.1680/ geot.1984.34.2.263.

[17] Zohdy, A.A. (1989): A new method for the automatic interpretation of Schlumberger and Wenner sounding curves. Geophysics, 54(2), pp. 245-253.

[18] Pandey, L.M., Shukla, S.K., Habibi, D. (2015): Electrical resistivity of sandy soil. Géotechnique Letters, 5(3), pp. 178-185, DOI: 10.1680/ jgele.15.00066.

[19] Lowrie, W. (2007): Fundamentals of geophysics. Cambridge University Press.

[20] Telford, W.M., Geldart, L.P., Sheriff, R.E. (1990): Applied geophysics. Cambridge University Press: Cambridge, U.K.

[21] Zohdy, A.A. (1975): Automatic interpretation of Schlumberger sounding curves using modified Dar Zarrouck functions. Geological Survey Bulletin, 1313E, pp. 39, DOI: 10.3133/b1313E.

[22] Keller, G.V., Frischnecht, F.C. (1966): ElectricaI methods in geophysical prospecting. Pergamon Press: Oxford England.

[23] Dahlin, T. (1996): 2D resistivity surveying for environmental and engineering applications. First Break, 14(1137), pp. 275-283, DOI: 10.3997/13652397.1996014.

[24] Zulfadhli, H.A., Mohd, H.M., Khairul Arifin, M.N. (2010): Electrical resistivity of subsurface: Field and laboratory assessment. World Academy of Science, Engineering and Technology, 45(1), pp. 799-m802.

[25] Keller, G.V. (1975): DC resistivity methods for determining resistivity in the earth's crust. Physics of the Earth and Planetary Interiors, 10(3), pp. 201-208, DOI: 10.1016/0031-9201(75)90046-1.

[26] Samouëlian, A. C., Isabelle, T.A., Bruand, A.G. (2005): Electrical resistivity survey in soil science: A review. Soil and Tillage Research, 83(2), pp. 173-193, DOI: 10.1016/j.still.2004.10.004.

[27] Nicholas, O. (1986): Schlumberger vertical soundings: Techniques and interpretations with examples from Kr1suv1k and Glerardalur, Iceland and Olkaria, Kenya, Geothermal Training Programme, United Nations University. 